\title{
ZARZADZANIE PROCESOWE Z WYKORZYSTANIEM WIEDZY W POLSKICH PRZEDSIĘBIORSTWACH
}

DOI: $10.33141 /$ po.2020.01.02

\author{
Agnieszka Bitkowska, Olga Sobolewska
}

\section{Wprowadzenie}

$\mathbf{R}$ ozwój zarządzania procesowego w działalności przedsiębiorstw stawia przed organizacjami nowe wyzwania, wynikające z turbulencji otoczenia oraz zachodzących zmian technologicznych, społecznych i ekonomicznych (Kiełtyka, Charciarek, 2019; Grajewski, 2012; Długosz i in., 2018). Potrzeba podejmowania takich działań spowodowana jest również przez krótkie cykle życia produktów, a także wzrost znaczenia wartości niematerialnych $\mathrm{w}$ tworzeniu przewagi konkurencyjnej organizacji (Koç i in., 2019; Gierszewska, 2020). Oznacza to konieczność właściwego kompletnego i spójnego podejścia do zarządzania procesowego bazującego na zasobach wiedzy. Ewolucja zarządzania procesowego stanowi odpowiedź na rosnącą turbulencję otoczenia i zachodzące zmiany wewnątrz przedsiębiorstwa, wzrost złożoności procesów wewnętrznych, zewnętrznych, a także indywidualizację potrzeb i oczekiwań klienta (Rosemann, vom Brocke, 2015; Mikuła, Stefaniuk, 2018).

Wymogi współczesnego otoczenia makro i mikro nie pozwalają na rozłączne traktowanie problematyki procesów i wiedzy. Przedsiębiorstwa, które decydują się na takie działanie, skazują się na porażkę rynkową w wyniku utraty możliwych efektów synergii, które mogłyby powstać, gdyby realizowane było podejście całościowe, integrujące te koncepcje zarządzania. Wykorzystanie wiedzy umożliwia osiągnięcie znacznych korzyści w zakresie uporządkowania sposobu działania przedsiębiorstwa, realizowanych procesów, obniżki kosztów, zwiększenia elastyczności i przejrzystości, identyfikacji procesów, orientacji na klienta i poprawy pozycji konkurencyjnej (Rostek i in., 2019).

Zarówno zarządzanie procesowe $\mathrm{w}$ organizacji, jak i kompleksowe zarządzanie wiedzą powinny być realizowane wspólnie, w ramach strategii przyjętej przez organizację. Ponadto rozłączne traktowanie problematyki procesów i wiedzy w przedsiębiorstwie powoduje utratę efektów synergii, które mogłyby powstać, gdyby uwzględniane było podejście całościowe.

Celem artykułu jest wskazanie stanu obecnego w zakresie zarządzania procesowego $\mathrm{z}$ wykorzystaniem wiedzy $\mathrm{w}$ polskich przedsiębiorstwach. Główne pytanie badawcze dotyczyło zagadnienia: $\mathrm{w}$ jaki sposób polskie przedsiębiorstwa zorientowane procesowo wykorzystują zasoby wiedzy? W publikacji zastosowano następujące metody i techniki badawcze: analizę literatury przedmiotu oraz analizę wyników badań własnych realizowanych w Polsce w 2019 roku. Przedstawione w artykule zagadnienia mają zarówno walor poznawczy, jak i praktyczny. 


\section{Zarządzanie procesowe - rozwój znaczenia koncepcji w aspekcie dynamicznych zmian otoczenia}

$\mathbf{P}$ ostępująca zmienność otoczenia, zwiększające się oczekiwania klientów oraz presja konkurencji wymagają od organizacji gotowości do elastycznego działania. Oznacza to, że organizacja powinna mieć zdolność do nauki, adaptacji do warunków otoczenia oraz szybkiego wewnętrznego przedefiniowania $\mathrm{w}$ zakresie realizowanych zadań, systemów i struktur. Organizacje funkcjonujące na rynku nieustannie prowadzą wymianę $z$ otoczeniem, a w jej wyniku muszą godzić się na adaptację do zmieniających się nieustannie warunków zewnętrznych. Wpływa to również na zachodzące $\mathrm{w}$ tych organizacjach procesy, które również powinny ulegać zmianom bardziej bądź mniej dogłębnym (Kiełtyka, Charciarek, 2019). Dotyczy to w szczególności tych działań, które związane są z tworzeniem i dostarczaniem dla klienta wartości, produktów bądź usług. Coraz częściej organizacje, w celu zaspokojenia potrzeb rynku, powinny personalizować swoje produkty bądź dostarczane usługi. Wymusza to na nich dokonywanie wielu zmian w dotychczasowych sposobach i metodach działania oraz konieczność doskonalenia procesów (Brajer-Marczak, 2018; Bitkowska, 2019).

W takich warunkach naturalną konsekwencją jest modyfikacja podejścia do zarządzania procesowego, które ewoluowało z klasycznego ujęcia typowego dla inżynierii przemysłowej i założenia o niezmienności procesu. W znaczeniu klasycznym modyfikacje procesu polegały na eliminacji nadmiarowych działań i jego stopniowym, ale wolnym usprawnianiu zgodnie z cyklem Deminga. Podejście procesowe to kompleksowe myślenie o procesach jako powiązanych ze sobą czynnościach. Zwiększenie efektywności funkcjonowania organizacji uzyskuje się poprzez identyfikację tych czynności oraz ich usprawnianie i nieustanne udoskonalanie. Zarządzanie procesowe rozumiane jako orientacja i doskonalenie realizowanych w ramach organizacji procesów jest podejściem, które funkcjonuje nierozłącznie z naukami o zarządzaniu. Klasyczne zarządzanie organizacją opierało się na założeniu, że należy tworzyć systemy możliwie najlepiej zrozumiałe dla ich wykonawców. Ze względu na fakt, że w przeszłości organizacje zatrudniały lub korzystały z usług nisko wykwalifikowanych pracowników, relacje między członkami organizacji były bardzo proste, a uczenie się ról w organizacji wymagało długotrwałego powtarzania tych samych działań. Podział odpowiedzialności był ściśle określony - na wykształconego i podejmującego decyzje przełożonego oraz wykonującego polecenia pracownika (Grajewski, 2012, s. 11).

Współcześnie należy wskazać na adaptację zachodzących $\mathrm{w}$ organizacjach procesów do wymagań klientów oraz o zarządzaniu procesowym i zarządzaniu wiedzą jako dwóch komplementarnych koncepcji, a nierozerwalnie połączonych wieloma wspólnymi elementami (Trocki, 2016; Bitkowska, 2018, s. 68) (rys. 1).

W literaturze przedmiotu prezentowane są poszczególne etapy zarządzania procesowego określane jako struktura zarządzania procesowego lub cykl zarządzania procesowego. S. Nowosielski (2018) proponuje cztery etapy w zakresie zarządzania procesowego: identyfikację procesów, modelowanie procesów, wdrażanie procesów oraz kierowanie (ocena funkcjonowania). Należy wskazać na konieczność doskonalenia procesów, ich symulacji oraz optymalizacji (Rosemann, vom Brocke, 2015; Brajer-Marczak, 2018; Bitkowska, 2019) .

Koncentracja na procesach pozwala na zwiększenie efektywności działania całej organizacji. Sprawność i skuteczność działania organizacji zarządzanych procesowo jest bezpośrednią pochodną sprawności realizowanych $\mathrm{w}$ nich procesów. Warunkiem sprzyjającym takiemu doskonaleniu i usprawnianiu funkcji organizacji jest istnienie procesów ustrukturalizowanych, czyli takich, które umożliwiają ich dokładne opisanie $\mathrm{w}$ formie algorytmu działania. Współcześnie jednak coraz mniej procesów zachodzących w organizacjach daje się zaliczyć do tej grupy procesów (Szelągowski, 2018).

\section{Proces zarządzania wiedzą w organizacjach}

$\mathbf{Z}$ arządzanie wiedzą jest koncepcją, która staje się standardowym rozwiązaniem w praktyce gospodarczej. Jest to efekt realizacji postulatu Nowej Ekonomii i rozwoju społeczeństwa informacyjnego, dla którego podstawowym zasobem jest informacja i wiedza, którą można dzięki niej budować (Prusak, 1996). Lata dziewięćdziesiąte XX wieku to czas, w którym powstaje zupełnie nowa kategoria produktu, który nie jest już utożsamiany tylko i wyłącznie z towarami i usługami. Coraz częściej przedmiotem wymiany handlowej staje się informacja i coraz częściej produkty finalne przyjmują formę cyfrową, niematerialną (Kisielnicki, Sobolewska, 2019). Coraz częściej zauważa się, że jedynie organizacje „uczące się”, czyli otwarte na wiedzę, jej pozyskiwanie i rozwijanie, mają szanse na osiągnięcie przewagi konkurencyjnej i w efekcie sukcesu rynkowego (Kisielnicki, Sobolewska, 2019).

Koncepcja łańcucha wartości jest cały czas aktualna i wykorzystywana w praktyce gospodarczej przedsiębiorstw (Value Network) (Kano, 2018). Podstawę tego łańcucha stanowią realizowane w niej procesy i interakcje pomiędzy uczestnikami organizacji. W efekcie ich realizacji powstają zarówno wartości materialne (jak choćby produkty), jak i niematerialne (czyli między innymi wiedza). Dlatego też zarządzanie wiedzą $\mathrm{w}$ organizacji powinno obejmować swoim zasięgiem wszystkie dostępne sfery

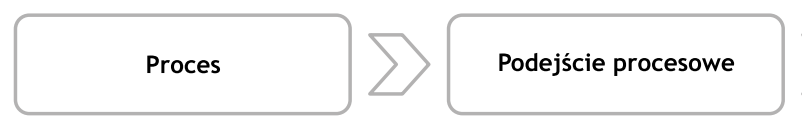


działalności, gdyż są one w sposób pośredni bądź bezpośredni wynikiem jej oddziaływania. Dzięki wiedzy organizacja nabywa zdolność do rozwiązywania problemów. Wiedza jest również fundamentem dla rozwoju innowacji w organizacjach (Gołębiowska-Tataj, 2013), które współcześnie coraz częściej stanowią o jej pozycji rynkowej. Nie ulega wątpliwości i potwierdzają to autorzy, iż wiedza jako zasób strategiczny powinna być nieustannie „w ruchu”, a zatem nieustannie identyfikowana, mierzona, pozyskiwana i rozwijana, a następnie wykorzystana i chroniona. (Verburg, Andriessen, 2011; Spraggon, Bodolica, 2017).

Budowanie takiej pozycji rynkowej wymaga od organizacji nieustannego zaangażowania $\mathrm{w}$ procesy zarządzania wiedzą. Nie wystarczy sam fakt posiadania wiedzy, ale musi być ona „w ruchu”. Wiedza nabiera znaczenia w chwili, gdy jest wykorzystywana (Kisielnicki, Sobolewska, 2019). Sam fakt jej posiadania i magazynowania nie tworzy wartości, wręcz przeciwnie, wykorzystywanie starej i nieaktualnej wiedzy skutkuje „wartością ujemną" dla organizacji (Krupski i in., 2009, s. 179). Z tej przyczyny zarządzanie wiedzą nie może być działaniem jednorazowym, musi stać się nieustannie zachodzącym w ramach organizacji procesem. Na proces zarządzania wiedzą składają się trzy subprocesy (Ŝmiałek, 2016, s. 115-116):

- dystrybucji wiedzy, dzięki której członkowie organizacji mają zagwarantowany dostęp do wiedzy znajdującej się w zasobach organizacji,

- organizacyjnego uczenia się, czyli pozyskiwania wiedzy i rozwijania aktualnie posiadanych zasobów,

- produkcji wiedzy, w wyniku której informacje zostają przekształcane na użyteczną „tu i teraz", z perspektywy organizacji, wiedzę.

Zarząazanie wiedzą jest procesem, który powinien być realizowany tak długo, jak długo działa organizacja. G. Probst, S. Raub i K. Romhardt (2002) zaprezentowali model, który wyodrębnia elementy, które bezpośrednio obejmuje zarządzanie wiedzą (rys. 2). Model przedstawia również powiązania między nimi oraz wskazuje na cykliczność realizowanych poszczególnych procesów w strukturze zarządzania wiedzą.

Procesy zarządzania wiedzą $\mathrm{w}$ organizacji wzajemnie na siebie wpływają i się przenikają. Można wprawdzie wyszczególnić etapy w cyklu zarządzania wiedzą i ich następstwa, jednak każdy z tych elementów może (i powinien) wpływać na kształt innych etapów tego cyklu. Podobne ujęcie znajdujemy u T. Davenporta i L. Prusaka (1998), którzy wskazują na trzy procesy zarządzania wiedzą (nabywania wiedzy, jej kodyfikacji i transferu), które również charakteryzują się tym, iż wzajemnie na siebie oddziałują. $\mathrm{W}$ ramach procesu nabywania wiedzy ma miejsce poszukiwanie informacji, jej źródeł, selekcjonowanie i ocena przydatności wiedzy, a następnie tworzenie jej i aktualizowanie istniejących w organizacji repozytoriów wiedzy. Proces kodyfikacji to zapisywanie wiedzy, przygotowywanie wiedzy do udostępniania $w$ organizacji. Proces transferu wiedzy to rozpowszechnianie zarówno w sposób formalny (np. newslettery, aktualizacje baz i repozytoriów, zmiany w procesach organizacyjnych), jak i w ramach kontaktów nieformalnych zachodzących w organizacji (Szelągowski, 2018, s. 144).

\section{Zarządzanie procesowe z wykorzystaniem wiedzy}

$\mathbf{N}$ aturalnym kierunkiem rozwoju dla współczesnych organizacji jest nie tylko dbałość o doskonałość procesową, ale również dbałość o stan zasobów wiedzy i wzmocnienie procesu zarządzania nią. Nie mogą być to odrębne procesy, a raczej konieczna jest ich synchronizacja i wzajemne połączenie. W tym przypadku można mówić o synergii pomiędzy tymi procesami, w wyniku której tworzona jest wartość dodatkowa, która może stanowić o uzyskaniu przewagi konkurencyjnej organizacji.

Proces zarządzania wiedzą nie powinien zachodzić w separacji od pozostałych procesów zachodzących w organizacji. We wcześniejszej części artykułu zwrócono uwagę na koncepcję łańcucha wartości, w którym wiedza stanowi koło napędowe dla realizowanych procesów. Wiedza, co już zostało zaakcentowane, jest uznawana za zasób o znaczeniu podstawowym. Jest o tyle specyficznym zasobem, że ujawnia się w trakcie działania i również $\mathrm{w}$ wyniku jej użytkowania - wtedy dochodzi do jej rzeczywistego rozwoju. Stąd wszelkie próby dokładnego oszacowania zasobów wiedzy pozostających $\mathrm{w}$ gestii organizacji są niezwykle trudnym zadaniem, gdyż jej rzeczywisty zakres może znacznie różnić się od uprzednio zadeklarowanego.

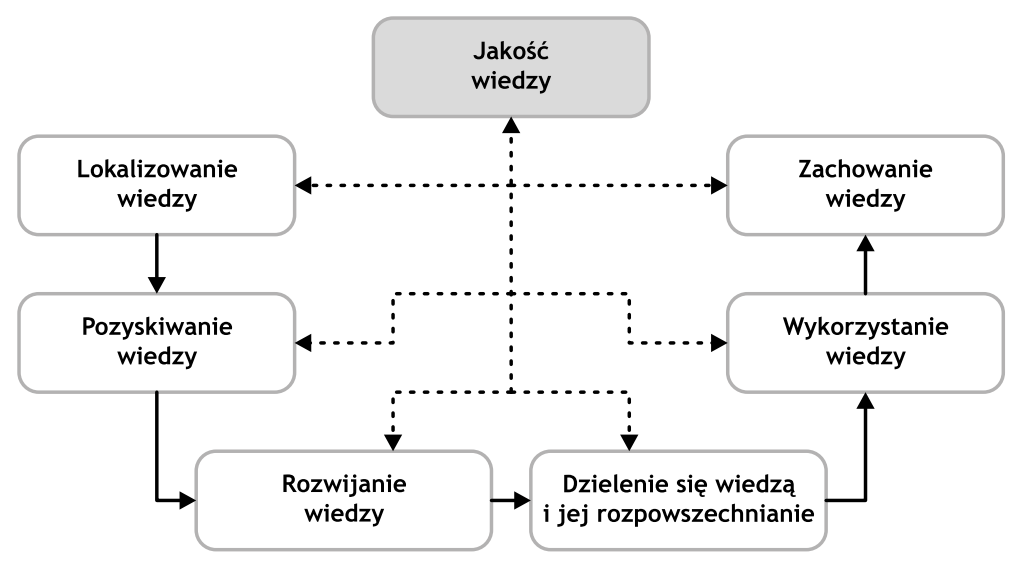

Rys. 2. Elementy procesu zarządzania wiedzą

Źródło: opracowanie wtasne na podstawie: Probst i in., 2002, s. 46 


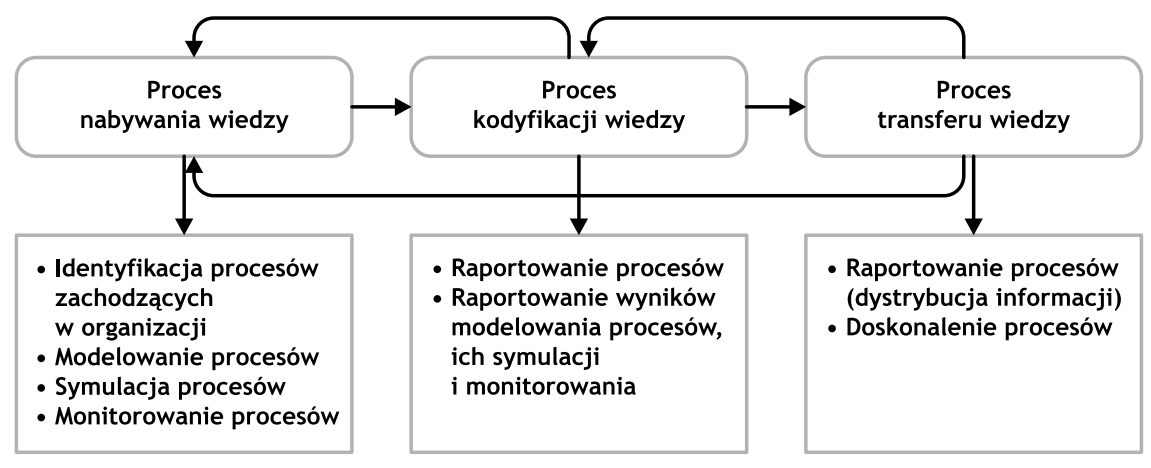

Rys. 3. Model procesowy zarządzania wiedzą

Źródło: opracowanie własne na podstawie: Szelągowski, 2018, s. 144

Zarządzanie procesowe również coraz silniej, wskazuje na procesowe zarządzanie zorientowane na wiedzę jako odpowiedź na wymagania nieustannie zmieniających się uwarunkowań gospodarczych. Zachodzące wewnątrz organizacji procesy biznesowe stanowią katalizator dla tworzenia i pogłębiania zasobów wiedzy. Konsekwencją uruchomienia procesu $\mathrm{w}$ organizacji jest nie tylko konieczność wykorzystania zasobów wiedzy, ale podejście procesowe wkomponowuje się $\mathrm{w}$ cały proces zarządzania wiedzą, począwszy od definiowania potrzeb, a skończywszy na zachowywaniu i ochronie wiedzy. Połączenie tych dwóch podejść, czyli kompleksowego zarządzania wiedzą $\mathrm{z}$ zarządzaniem procesaowym, może $\mathrm{w}$ efekcie umożliwiać:

- poszukiwanie i pozyskiwanie wiedzy procesowej w celu doskonalenia przedsiębiorstwa oraz wprowadzania innowacyjnych rozwiązań,

- transfer i wykorzystanie specjalistycznej wiedzy oraz know-how

- skuteczniejszą współpracę między pracownikami,

- udostępnienie odpowiednich zasobów wiedzy menedżerom procesów oaz pozostałym pracownikom w organizacji,

- dzielenie się wiedzą wewnątrz zespołów procesowych i pomiędzy zespołami,

- wpływ na innowacyjność pracowników poprzez poprawę komunikacji.

Wdrożenie takiego podejścia do zarządzania procesowego $\mathrm{w}$ przedsiębiorstwie jest działaniem koniecznym, ale niełatwym. Organizacje muszą, w świetle wymogów rynkowych, umożliwiać swoim pracownikom codzienne wykorzystywanie i tworzenie wiedzy w ramach zachodzących procesów biznesowych. Organizacje te muszą również intensywnie monitorować zmieniający się rynek, $\mathrm{w}$ najsilniejszym stopniu w dziedzinie dostawców rozwiązań informatycznych, tak aby adaptować funkcjonujące $\mathrm{w}$ organizacji systemy w celu uniknięcia luki technologicznej (Szelągowski, 2018, s. 67).

Wykorzystywanie koncepcji zarządzania wiedza $\mathrm{w}$ procesowym zarządzaniu organizacją $\mathrm{w}$ pełni wpisuje się w cytowane we wcześniejszej części artykułu ujęcia zarządzania wiedzą (rys. 3).

Szczególnie widoczne na zestawieniu pokazanym na rysunku 3 jest to, że trudno o jednoznaczne przyporządkowanie działania do jednej konkretnej grupy działań.
Wskazuje to ponownie na konieczność przenikania się poszczególnych aktywności dla efektywnego zarządzania wiedzą procesową w organizacji.

\section{Analiza wyników badań realizowanych w polskich przedsiębiorstwach zorientowanych procesowo}

B adania przeprowadzono w 2019 r. w Polsce wśród 182 przedsiębiorstw zorientowanych procesowo $\mathrm{z}$ wykorzystaniem kwestionariusza ankiety realizowanego bezpośrednio, zawierającego zarówno pytania otwarte, jak i zamknięte. Doboru przedsiębiorstw do badań dokonano metodą celową, a respondentami badań byli menedżerowie, przedstawiciele kadry zarządzającej dysponujący odpowiednią wiedzą $\mathrm{w}$ zakresie inicjatyw zarządzania procesowego. Kwestionariusz ankiety został przygotowany na podstawie studiów literaturowych i doświadczeń z zakresu zarządzania procesowego w organizacjach (Bitkowska, 2019). Badano wykorzystanie zasobów wiedzy $\mathrm{w}$ organizacjach procesowych na poszczególnych etapach cyklu zarządzania procesowego m.in.: identyfikacji, modelowania, doskonalenia, jak również ich monitorowania czy raportowania.

Spośród 182 przedsiębiorstw, które zdecydowały się na uczestnictwo w ankiecie badawczej, jedynie 5 nie wykorzystuje w swojej działalności zarządzania wiedzą. Co jednak znaczące, aż 177 spośród nich rzeczywiście ma świadomość i aktywnie wykorzystuje procesy zarządzania wiedzą albo dla całej organizacji, albo dla wybranych obszarów jej działalności (rys. 4). Dalsze analizy opisane w treści artykuły dotyczą próby badawczej 177 przedsiębiorstw i są pytaniami o ich bezpośrednie doświadczenia związane $\mathrm{z}$ wykorzystaniem zarządzania wiedzą w zarządzaniu zorientowanym na procesy.

Prezentowane w części teoretycznej rozważania znajdują odzwierciedlenie $\mathrm{w}$ realizowanej części badawczej (rys. 3). W przypadku zarządzania procesowego opartego na zasobach wiedzy mamy do czynienia $\mathrm{z}$ pozyskiwaniem wiedzy, jej utrwaleniem w zachodzących procesach oraz upowszechnieniem wiedzy $w$ ramach organizacji. Wszelkie te działania, podejmowane przez organizacje, mają na celu odniesienie wymiernych korzyści, które stanowią odpowiedź na wyzwania stawiane przez współczesny rynek. Organizacje, które zadeklarowały, iż 
w ramach ich procesów, tematyka wiedzy i zarządzania nią pełni istotne miejsce, zostały zapytane o rzeczywiste korzyści, które wynikają bezpośrednio z podejmowanych przez nie działań. Pierwszym etapem, zarówno w przypadku zarządzania procesowego, jak i zarządzania wiedzą w organizacji, jest jej lokalizacja. Chodzi tu o wskazanie źródeł informacji, określenie miejsc, z których ta informacja może pochodzić i gdzie należy jej szukać. W przypadku zarządzania w organizacji elementem koniecznym, wpisującym się w zarządzanie procesowe, jest identyfikacja i wskazanie procesów w niej zachodzących. Jest to konieczny element działania, gdyż dopiero określony, opisany proces można dalej analizować, poddawać symulacji i dokonywać jego poprawy, optymalizować. Uwzględnionych w badaniach 177 organizacji zarządzanych procesowo zapytanych zostało o to, czy identyfikacja procesów w ich działalności skutkuje dla przedsiębiorstwa korzyściami. W konsekwencji, czy jest to działanie, które należy podejmować. Odpowiedzi były w tym przypadku prawie jednoznaczne (rys. 5). Jedynie $1,13 \%$ organizacji zdecydowanie nie widzi takich korzyści. Jednocześnie na korzyści z tego działania wskazuje ponad $70 \%$ ankietowanych organizacji.

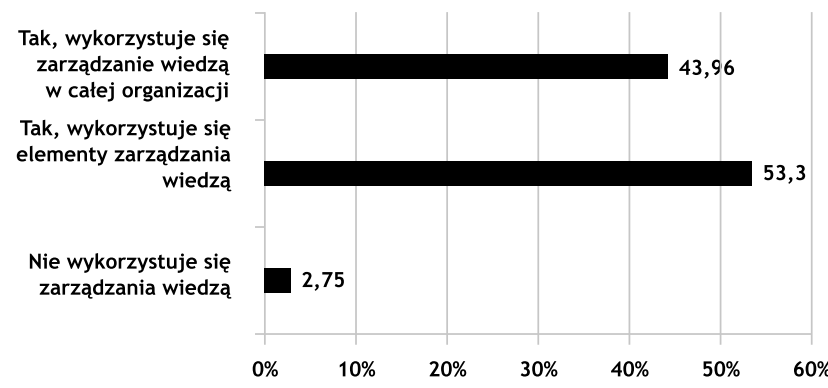

Rys. 4. Wykorzystanie koncepcji zarządzania wiedzą w zarządzaniu procesowym

Źródto: opracowanie własne

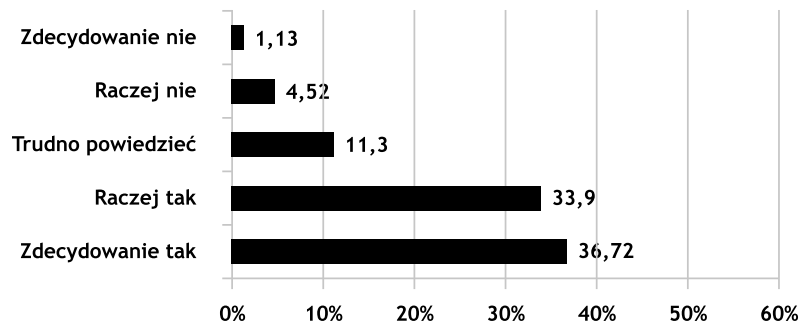

Rys. 5. Korzyści z etapów realizacji zarządzania procesowego $z$ wykorzystaniem wiedzy - identyfikacja procesów

Zródto: opracowanie własne

Podobną sytuację można zaobserwować w przypadku kolejnych etapów zarządzania procesowego - modelowania oraz optymalizacji. Przeważająca część organizacji spośród tych, które uczestniczyły w badaniu, wskazuje, na istnienie korzyści bezpośrednio wynikających z faktu wykorzystania wiedzy w modelowaniu procesów (rys. 6) oraz optymalizowania procesów zachodzących w organizacji (rys. 7).
Na podstawie modeli procesów zachodzących w organizacji oraz wyników ich optymalizacji podejmowane są działania symulacyjne. Wynika to $\mathrm{z}$ faktu, iż przed wdrożeniem procesu konieczne jest sprawdzenie, w jaki sposób proces będzie przebiegał i jakie będzie miał skutki na organizację, produkt bądź jej otoczenie. $Z$ tej przyczyny dokonuje się symulacji. W tym przypadku zdania nie są aż tak jednoznaczne, jak było w poprzednich pytaniach (rys. 8). Znaczna część organizacji nie potrafi określić, czy prowadzona symulacja działań ma skutki korzystne dla organizacji. Wytłumaczyć to można faktem, iż korzyści bezpośrednie wynikające $\mathrm{z}$ dokonania symulacji nie są w rzeczywistości wymierne. Potencjał symulacji widzą z kolei menedżerowie wskazujący na odpowiedź „raczej tak”, gdyż działania te pozwalają na uniknięcie przyszłych, niekiedy kosztownych błędów w procesach. Umożliwia to lepsze projektowanie procesów oraz przeprowadzenie ich weryfikacji w bezpiecznym środowisku testowym.

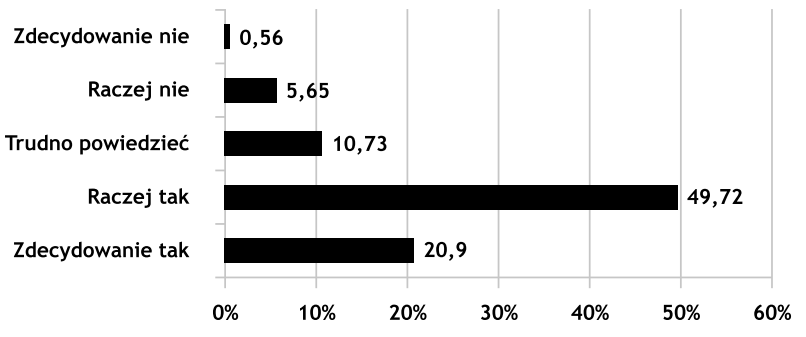

Rys. 6. Korzyści z etapów realizacji zarządzania procesowego z wykorzystaniem wiedzy - modelowania procesów Źródło: opracowanie wtasne

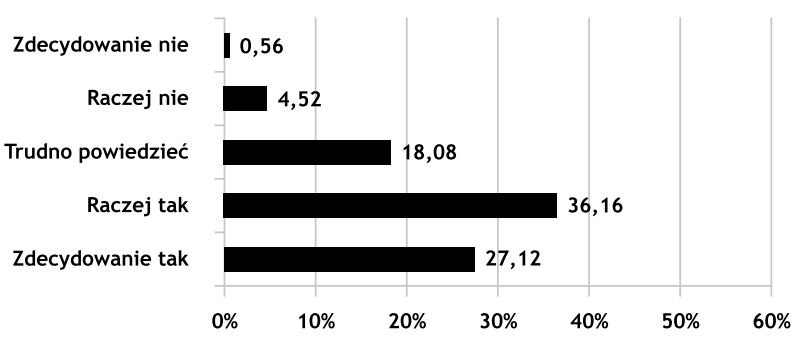

Rys. 7. Korzyści z etapów realizacji zarządzania procesowego z wykorzystaniem wiedzy - optymalizacja procesów Źródło: opracowanie wtasne

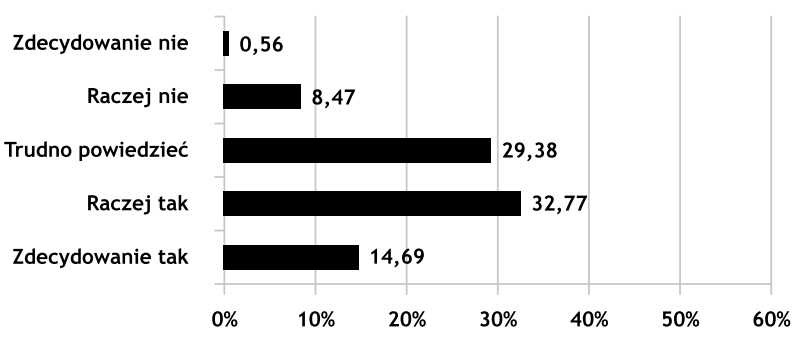

Rys. 8. Korzyści z etapów realizacji zarządzania procesowego z wykorzystaniem wiedzy - symulacja procesów Źródło: opracowanie własne

Kolejne dwa pytania, których wyniki zostały przestawione na rysunkach 9 i 10, odnoszą się do monitorowania procesów realizowanych $\mathrm{w}$ organizacjach oraz ich 
raportowania. W obu przypadkach wynik ankiet wygląda w sposób bardzo podobny, a udzielane odpowiedzi są porównywalne. Może być to wynikiem bezpośredniego powiązania tych dwóch czynności ze sobą, gdzie w wyniku prowadzonego monitoringu pisze się raporty i w wyniku tych działań dochodzi do kodowania wiedzy procesowej.

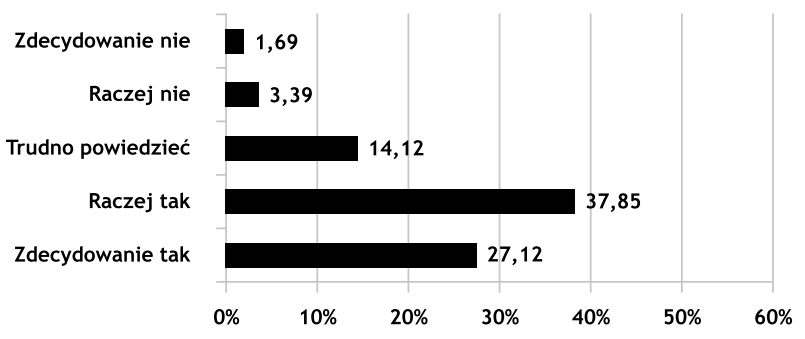

Rys. 9. Korzyści z etapów realizacji zarządzania procesowego z wykorzystaniem wiedzy - monitorowanie procesów Źródło: opracowanie własne

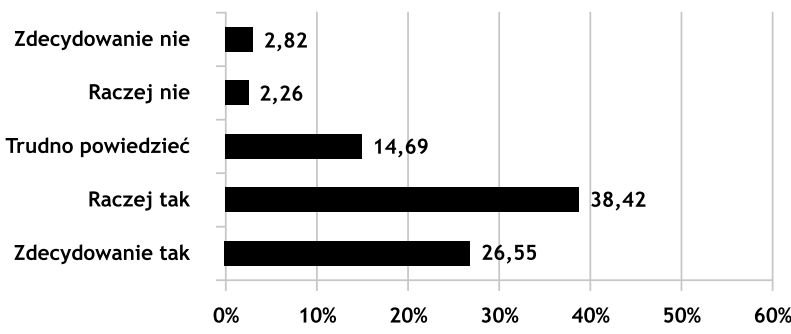

Rys. 10. Korzyści z etapów realizacji zarządzania procesowego z wykorzystaniem wiedzy - raportowanie procesów Źródło: opracowanie własne

Pytanie o korzyści dla organizacji, które są bezpośrednim wynikiem doskonalenia procesów, podobnie jak pozostałe, spotkało się z dużą aprobatą ankietowanych (rys. 11). Co ciekawe, aż 26 organizacji spośród 177, które wzięły udział w badaniu ankietowym, nie potrafi jednoznacznie odpowiedzieć na pytanie o korzyści wynikające $\mathrm{z}$ doskonalenia procesów. Może to jednak wynikać $\mathrm{z}$ faktu, iż faktyczne korzyści zostaną odnotowane w dłuższym horyzoncie czasowym, a organizacja nie dokonała jeszcze odpowiednich pomiarów. Znacznie bardziej niepokojącym wyjaśnieniem w tym przypadku byłoby to, że organizacje nie mierzą efektów podejmowanych działań. Jest to oczywiście możliwe, choć przeprowadzona ankieta nie obejmowała tego zagadnienia.

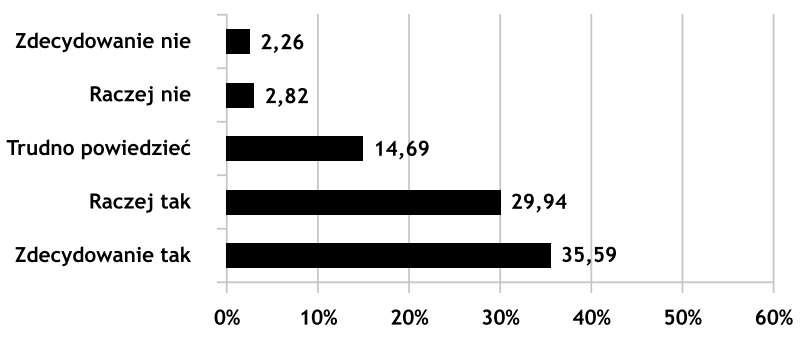

Rys. 11. Korzyści z etapów realizacji zarządzania procesowego z wykorzystaniem wiedzy - doskonalenie procesów Źródło: opracowanie własne
Wprowadzenie $\mathrm{w}$ organizacjach zarządzania procesowego oraz zarządzania wiedzą powinno mieć na celu poprawienie efektywności i skuteczności funkcjonowania organizacji. Wiąże się to $\mathrm{z}$ monitorowaniem procesów oraz ich kontrolą. W praktyce kontrola ta ma miejsce dzięki systematycznemu śledzeniu wskaźników, określanych jako kluczowe współczynniki efektywności (KPI). Każda organizacja samodzielnie określa szereg czynników, które najpełniej raportują o prawidłowości bądź pojawiających się problemach, w realizowanych przez nie procesach. Pytanie, które zostało zadane organizacjom uczestniczącym w badaniu ankietowym, koncentrowało się właśnie na pozytywnym wpływie faktu wprowadzenia dostępu do wiedzy procesowej na jakość procesów mierzoną za pomocą istotnych dla nich współczynników (rys. 12). Ponad połowa ankietowanych przyznała, że taki pozytywny wpływ ma miejsce, przy czym aż co piąty ankietowany wyraźnie wskazywał na pozytywną korelację pomiędzy współczynnikami efektywności procesów a wykorzystywaniem $\mathrm{w}$ organizacji zarządzania procesowego zorientowanego na zasoby wiedzy. Na negatywne efekty wskazywało jedynie $4,52 \%$ ankietowanych. Ciekawą obserwacją może być fakt, iż najliczniejszą grupą widoczną na rysunku 9 są organizacje, które nie potrafią dokonać oszacowania wpływu zarządzania procesowego opartego na wiedzy na wartość współczynników efektywności. Autorki uważają, iż w tym przypadku można odrzucić wyjaśnienie, które mówi o braku stałego monitoringu. Sam fakt wyszczególnienia KPI w organizacjach wymusza na nich konieczność ich obserwowania. Dodać należy, iż, co już zostało podkreślone we wcześniejszej części artykułu, przedsiębiorstwa uczestniczące w badaniu zostały dobrane metodą celową. Nie są to przypadkowe, losowe organizacje, lecz takie, które wdrożyły w swoich strukturach zarządzanie procesowe. Wiąże się to nierozerwalnie $\mathrm{z}$ rygorem monitorowania i nieustannej obserwacji realizowanych w nich procesów. Wyjaśnienia, ku którym skłaniają się autorki, są dwa. Jedno z nich sugeruje, iż przedsiębiorstwa niedawno wprowadziły dostęp do wiedzy procesowej. Krótki horyzont czasowy powoduje, iż dysponują one liczbą obserwacji, która nie wystarcza dla podjęcia jednoznacznej decyzji. Drugim wyjaśnieniem jest to, iż w warunkach nieustannych zmian rynkowych, które wymuszają dokonywanie zmian $\mathrm{w}$ samych procesach produkcyjnych, nie jest możliwe dokonanie pełnej i obiektywnej oceny wskaźników przed i po wdrożeniu zarządzania procesowego opartego na wiedzy.

Podobnie jak w przypadku poprzedniego zagadnienia, jakim były współczynniki efektywności w pytaniu o poziom zadowolenia klientów, mamy również wskazania, w których znaczna większość (68\% ankietowanych) podkreśla podniesienie poziomu zadowolenia klientów, które jest wynikiem wprowadzenia w organizacji zarzadzania procesowego zorientowanego na wiedzę (rys. 13). Podobnie jak w poprzednim pytaniu, dość duża grupa ankietowanych (aż 18,64\%) nie potrafiła jednoznacznie udzielić odpowiedzi. Wyjaśnienie tego zjawiska, podobnie jak w przypadku pytania o współczynniki efektywności, mogłoby stanowić podstawę do dalszych, pogłębionych badań ankietowych. 


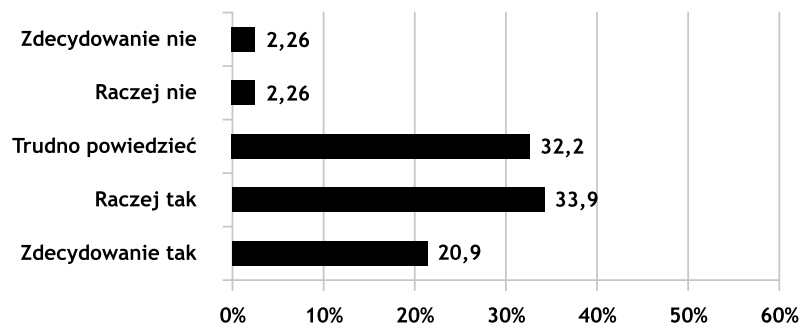

Rys. 12. Optymalizacja KPI, kosztów, czasów procesów poprzez dostęp do wiedzy procesowej

Źródto: opracowanie wtasne

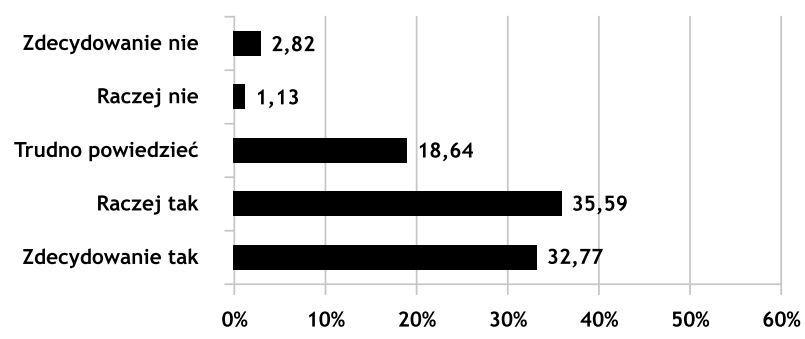

Rys. 13. Podniesienie poziomu zadowolenia klientów poprzez dostęp do wiedzy procesowej

Źródło: opracowanie własne

Analizując efekty przeprowadzonych badań, można stwierdzić, że niewątpliwie organizacje widzą szansę dla poprawy swojej efektywności i dla wzmocnienia swojej pozycji konkurencyjnej poprzez wdrażanie zarządzania procesowego opartego na wiedzy. Widoczne jest to wyraźnie w strukturze odpowiedzi na pytania badawcze. Organizacje zaproszone do udziału w badaniu należą do grupy tych, które są świadome zachodzących w nich procesów i jednocześnie zdają sobie sprawę z ich znaczenia dla ich obecnego i przyszłego funkcjonowania. Są to organizacje, które w swojej działalności wdrożyły zarządzanie procesowe, a znaczna większość z nich świadomie wykorzystuje również elementy zarządzania wiedzą bądź nawet wdraża tę koncepcję całościowo. Jest to niewątpliwą oznaką zachodzących na rynku zmian, a zważywszy na znaczącą (aż 182 celowo wybranych organizacji) próbę badawczą, możemy mówić o występującym na rynku polskim rzeczywistym trendzie polegającym na łączeniu zarządzania procesowego z zarządzaniem wiedzą organizacyjną. Przedsiębiorstwa, które zdecydowały się na wykorzystywanie zarządzania procesowego zorientowane- go na zasoby wiedzy, muszą być gotowe do podejmowania zmian. Widoczne jest to w odpowiedziach na pytania dotyczące kolejnych etapów zarządzania procesowego. Sam fakt wykorzystywania zasobów wiedzy powoduje, iż organizacje muszą być gotowe do nieustannej identyfikacji, modelowania, optymalizowania, symulowania, monitorowania, raportowania i doskonalenia zachodzących w nich procesów. Interesujące wnioski można sformułować, analizując zestawienie pozytywnych i negatywnych efektów wynikających dla organizacji z realizacji tych kolejnych elementów zarządzania projektowego opartego na wiedzy (tab. 1).

O ile efekty pozytywne odnotowywane przez przedsiębiorstwa nie budzą większych uwag ani zastrzeżeń, gdyż są one potwierdzeniem zasadności podejmowanych działań, o tyle ciekawą stroną zestawienia jest strona pokazująca efekty negatywne i brak ocen. Wyróżnia się w tym zakresie pierwszy z elementów, jakim jest identyfikacja zachodzących procesów. Jest to szczególnie znamienne, gdyż ten etap determinuje często o sukcesie dalszych działań. Wyraźnie widoczna jest jednak ogromna przewaga odpowiedzi wskazujących na korzyści związane $\mathrm{z}$ wdrażaniem zarządzania procesowego opartego na wiedzy. Jest to kolejny znak, iż podejście to zyskuje nie tylko na popularności w sferze literatury przedmiotu, ale staje się codziennością w funkcjonowaniu polskich przedsiębiorstw.

\section{Podsumowanie}

$\mathbf{Z}$ arządzanie procesowe zorientowane na wiedzę znajduje odzwierciedlenie zarówno w podejściu teoretycznym, jak i praktycznym, co zostało zaobserwowane w wyniku analizy badań w polskich przedsiębiorstwach. Procesy, które organizacja realizuje w sposób sprawny i efektywny, są czynnikiem budującym dobrą opinię o organizacji, nie tylko z perspektywy jej menedżerów, ale również klientów. Sprawnie realizowane i doskonalone procesy są czynnikiem, który wpływa na efektywność przedsiębiorstwa i jego konkurencyjność.

Celem artykułu było wskazanie stanu obecnego w zakresie zarządzania procesowego $\mathrm{z}$ wykorzystaniem wiedzy w polskich przedsiębiorstwach. Dla zrealizowania tego celu zostało przeprowadzone badanie ankietowe w organizacjach, które w swojej działalności koncentrują się na procesach. Są to organizacje, które są świadome istnienia swoich procesów i konieczności ich rozwijania. W przeprowadzonych

Tabela 1. Zestawienie efektów wynikających z wdrożenia zarządzania procesowego zorientowanego na wiedzę w polskich organizacjach

\begin{tabular}{|c|c|c|c|}
\hline Elementy zarządzania procesowego & Efekty pozytywne & Efekty negatywne & Brak oceny \\
\hline Identyfikacja procesów & $70,69 \%$ & $15,65 \%$ & $11,30 \%$ \\
\hline Modelowanie procesów & $70,62 \%$ & $6,21 \%$ & $10,73 \%$ \\
\hline Optymalizacja procesów & $63,28 \%$ & $5,08 \%$ & $18,08 \%$ \\
\hline Symulacja procesów & $47,46 \%$ & $9,03 \%$ & $29,38 \%$ \\
\hline Monitorowanie procesów & $64,97 \%$ & $5,08 \%$ & $14,12 \%$ \\
\hline Raportowania procesów & $64,97 \%$ & $5,08 \%$ & $14,69 \%$ \\
\hline Doskonalenie procesów & $65,53 \%$ & $4,57 \%$ & $14,69 \%$ \\
\hline
\end{tabular}

Źródto: opracowanie wtasne 
badaniach szczególnie widoczne jest to, że przedsiębiorstwa te idą „krok dalej”. Zdają sobie sprawę ze zmienności stającej się cechą charakterystyczną dla dzisiejszej gospodarki. Organizacje te również uświadamiają sobie konieczność nie tylko dbałości o aktualnie realizowane w nich procesy, ale również na adaptacje ich do zmian narzucanych przez otoczenie, a także tych, które bezpośrednio pochodzą $\mathrm{z}$ ich wnętrza. $\mathrm{W}$ tym celu wdrażają zarządzanie procesowe bazujące na wiedzy. Pamiętać należy, iż nie jest to dla przedsiębiorstwa zmiana błaha. Proces integracji systemów zarządzania wiedzą $\mathrm{z}$ aktualnie realizowaną orientacją procesową jest działaniem długoterminowym i wymagającym zastosowania szerokiego spektrum narzędzi i zasobów. Stąd też tak liczna grupa organizacji, która takie działania prowadzi bezpośrednio, może wskazywać na obowiązujący trend rynkowy, który w najbliższym okresie będzie się umacniał.

Badania, które stanowiły kanwę dla artykułu, mają charakter wstępny. Pokazały one zachodzące zjawiska oraz ich znaczenie dla organizacji zarówno z perspektywy samych procesów, jak i ocen ekonomicznej i rynkowej. Badania te pokazały również szereg obszarów, które powinny, zdaniem autorek, zostać zbadane w sposób ukierunkowany. Jako kierunki dalszych badań wskazać można wątpliwości i pytania, które pojawiają się $\mathrm{w}$ wyniku dokonania analizy danych przedstawionych w artykule. Pytania te dotyczą w głównej mierze tego, jaką drogę wybierają organizacje celowo rezygnujące $\mathrm{z}$ integracji zarządzania procesowego $\mathrm{z}$ zarządzaniem wiedzą. Podobnie istotnym zagadnieniem jest analiza negatywnych doświadczeń organizacji, które wprawdzie nie stanowiły znaczącej wartości w wynikach badań, ale sam fakt ich istnienia otwiera szereg pytań badawczych. Ciekawym rozwiązaniem byłoby powtórzenie badania i sprawdzenie, czy brak oceny wynika $z$ faktu, iż zarządzanie procesowe oparte na wiedzy jest stosunkowo nowym rozwiązaniem w polskich organizacjach.

Z pewnością jednak, co bezpośrednio potwierdzają przeprowadzone badania, mamy do czynienia $\mathrm{z}$ ogromnym zainteresowaniem i rzeczywistym wykorzystaniem koncepcji zarządzania wiedzą w zarządzaniu procesowym, jako podejścia w istotny sposób wpływającego na konkurencyjność współczesnych organizacji.

\section{dr hab. inż. Agnieszka Bitkowska, prof. uczelni Politechnika Warszawska$$
\text { Wydział Zarządzania }
$$$$
\text { ORCID: 0000-0002-2817-8244 }
$$ \\ e-mail: Agnieszka.Bitkowska@pw.edu.pl}

\section{dr inż. Olga Sobolewska \\ Politechnika Warszawska \\ Wydział Zarządzania \\ ORCID: 0000-0002-5377-2480 \\ e-mail: Olga.Sobolewska@pw.edu.pl \\ Bibliografia}

[1] Bitkowska A. (2019), Od klasycznego do zintegrowanego zarzadzania procesowego, Wyd. C.H. Beck, Warszawa.
[2] Bitkowska A. (2018), Zarzadzanie procesowe zorientowane na wiedze, [w:] G. Gierszewska (red.), Co dalej z zarządzaniem? Oficyna Wydawnicza PW, Warszawa, s. 19-33.

[3] Brajer-Marczak R. (2018), Czynniki determinujące doskonalenie procesów. Wyniki badań empirycznych, „Przegląd Organizacji”, Nr 8, s. 25-33.

[4] Davenport T., Prusak L. (1998), Working Knowlegde - How Organizations Manage What They Know, Harvard Business School, Boston.

[5] Długosz A., Rostek K., Zawiła-Niedźwiecki J. (2018), Wpływ nowych technologii na zarzadzanie. Technologiczne wyzwania biznesu - sztuczna inteligencja. Perspektywa Intel Polska, „Przegląd Organizacji”, Nr 7, s. 54-56.

[6] Gierszewska G. (red.), (2020), Zarządzanie w przedsiębiorstwie N.0. Droga do przyszłości, Oficyna Wydawnicza Politechniki Warszawskiej, Warszawa.

[7] Gołębiowska-Tataj D. (2013), Entrepreneurial Innovation Networks: Knowledge Triangle and Emerging Business Model, Oficyna Wydawnicza Politechniki Warszawskiej, Warszawa.

[8] Grajewski P. (2012), Procesowe zarzadzanie organizacja, Wyd. PWE, Warszawa.

[9] Kano L. (2018), Global Value Chain Governance: A Relational Perspective, „Journal of International Business Studies”, Vol. 49, No. 6, pp. 684-705.

[10] Kiełtyka L., Charciarek K. (2019), Model zarzadzania procesowego $z$ wykorzystaniem nowoczesnych narzędzi Przemysłu 4.0, „Przegląd Organizacji”, Nr 8, s. 5-12.

[11] Kisielnicki J., Sobolewska O. (2019), Knowlegde Management and Innovation in Network Organizations, IGI Global, Hershey.

[12] Koç T., Kadir K., Adem A. (2019), A Brief Summary of Knowledge Management Domain: 10-Year History of the Journal of Knowledge Management, „Procedia Computer Science”, Vol. 158, pp. 891-898.

[13] Krupski R., Niemczyk J., Stańczyk-Hugiet E. (2009), Koncepcje strategii organizacji, Wyd. PWE, Warszawa.

[14] Mikuła B., Stefaniuk T. (2018), Zagrożenia dla bezpieczeństwa wiedzy $w$ ramach zarzadzania wiedza klienta, „Przegląd Organizacji”, Nr 9, s. 21-28.

[15] Nowosielski S. (2018), Procesy i projekty $w$ organizacji. O potrzebie i sposobach współdziałania, „Studia i Prace Kolegium Zarządzania i Finansów”, Nr 169, s. 109-130.

[16] Probst G., Raub S., Romhardt K. (2002), Zarzadzanie wiedza w organizacji, Oficyna Ekonomiczna, Kraków.

[17] Prusak L. (1996), The Knowledge Advantage, „Strategy and Leadership", Vol. 24, pp. 6-8.

[18] Rosemann M., vom Brocke J. (2015), Handbook on Business Process Management 2: Strategic Alignment, Governance, People and Culture, Springer.

[19] Rostek K., Wiśniewski M., Zając R. (2019), Zarządzanie komunikacja $i$ wiedza $w$ planowaniu cywilnym oraz zarzadzaniu kryzysowym, Oficyna Wydawnicza Politechniki Warszawskiej, Warszawa.

[20] Spraggon M., Bodolica V. (2017), Collective Tacit Knowledge Generation through Play: Integrating Socially Distributed Cognition and Transactive Memory Systems, „Management Decision", Vol. 55, No. 1, pp. 119-135.

[21] Szelągowski M. (2018), Zarzadzanie procesowe w gospodarce wiedzy. Tworzenie wartości z kapitału intelektualnego, Wydawnictwo Linia, Warszawa. 
[22] Śmiałek P. (2016), Zarządzanie wiedzą wyzwaniem współczesnych organizacji, „Acta Universitatis Nicolai Copernici”, Nr 2, s. 113-123.

[23] Trocki M. (2016), Inteligencja procesowa, czyli inteligentne zarządzanie procesowe, „Studia i Prace Kolegium Zarządzania i Finansów Szkoły Głównej Handlowej”, Nr 149, s. 171-184.

[24] Verburg R., Andriessen E.J. (2011), A Typology of Knowledge Sharing Networks in Practice, „Knowledge and Process Management", Vol. 16, No. 1, pp. 34-44.

\section{Knowledge-oriented Process Management in Polish Organisations}

\section{Summary}

Modern organisations face the need to adapt their structures and processes taking place in them to the requirements of the constantly changing markets. Organisation process management has been indicated both in the lit- erature and practice as a particularly important element of management. Nowadays, the importance of knowledge and its use in improving organisational processes is increasingly emphasised. The purpose of the article is to indicate the current state in the field of Business process management using knowledge in Polish organisations. The article quotes own research carried out in 2019 in Polish process-managed enterprises. The research indicates that Polish enterprises are also aware of the need to care both for the processes currently implemented and changes dictated by the environment and resulting from internal conditions of companies. Implementation of knowledge-based process management is increasingly used to achieve these goals.

\section{Keywords}

business process management, knowledge management, knowledge-oriented business process management 